\title{
Strategic management of the development of an innovative energy efficient cluster
}

\author{
Alexey Palamarchuk ${ }^{1, *}$ \\ ${ }^{1}$ Moscow Aviation Institute, 4, Volokolamskoe highway, Moscow, 125993, Russia
}

\begin{abstract}
One of the most important areas of innovative development of economic systems of Russian regions is the formation of clusters. The global changes occurring in the innovation economy within the framework of the Fourth Industrial Revolution predetermine the emergence of new requirements for the created clusters, including the systemic digitalization of enterprises and organizations that are part of them, as well as increasing their energy efficiency. Taking into account these requirements, the author proposes a new type of cluster structure - an innovative energy efficient cluster. The author develops the structure of the program for the strategic development of an innovative energy efficient cluster, in which seven strategies are identified, reflecting the key directions of its development. As part of the final section of the program, the author develops a classification of target indicators of the effectiveness of implementation of the strategic development program.
\end{abstract}

\section{Introduction}

The intensification of the development processes of the Russian innovation economy in the last decade has led to serious structural changes in the industrial sphere, causing manufacturers to continuously search for more efficient forms and technologies for organizing production. As noted by R.S. Golov et al., this is largely caused by the government's deployment of a set of measures aimed at re-industrializing the economy and solving the problem of import substitution [1-2]. One of the most ambitious trends in the innovative development of industry has become the construction of clusters as holistic structures that expand the technological, technical and economic capabilities of their participants due to the factor of geographical proximity and end-to-end mechanisms of network interaction [3]. Successful experience in the development of such integrated structures in regional economic systems has proven that clusters can become active points of innovation and economic growth in regions [4-5].

Increased requirements for the level of their energy efficiency and resource conservation have become an important criterion for the efficiency of clusters in the era of the Fourth Industrial Revolution [6-7]. The solution to the problem of increasing the energy efficiency of production in the context of Industry 4.0 is facilitated by the progress introduced by digitalization in the field of energy metering and energy saving systems and technologies,

* Corresponding author: palamarchuk.ag@mail.ru 
allowing them to be organically integrated as links in the overall digital infrastructure of the cluster. This allows expanding the capabilities of modern enterprises and clusters to reduce the overhead of fuel and energy resources [8-9].

Taking into account the need to adapt the Russian cluster economy to these changes, the author has developed a new type of cluster formations focused on effective development in conditions of the technological landscape of Industry 4.0 - an innovative energy-efficient cluster. According to the author's definition, an innovative energy-efficient cluster is understood as a geographically integrated complex of industrial enterprises, universities, research and development organizations, infrastructure organizations, and a specialized energy service company united by a single digital environment, within which the participants carry out a sole and joint development and implementation into production of innovation and investment projects in compliance with the energy efficiency targets set in the cluster and the implementation of an active energy conservation policy.

One of the most important areas of cluster development in the context of Industry 4.0 is the formation of an effective strategy for their development. The proposed study reveals the essence and foundations of strategic management of the development of an innovative energy efficient cluster in the digital economy.

\section{Literature review}

Studies of the results of integration into technological systems and infrastructure of clusters of Industry 4.0 technologies are currently being carried out in many countries. As G. Dalmarco et al. note in their study using the analysis of the Portuguese PRODUTECH cluster as an example, the use of Industry 4.0 technologies by its participants allows them to customize their own production and introduce completely new business models of product commercialization [10]. The significant influence of Industry 4.0 on the development of clusters is also noted in the study by M. Götz [11].

Special attention is paid by modern scientists to the problem of energy efficiency of enterprises in the era of the Fourth Industrial Revolution. Thus, Indian scientists A. Shukla and R. Nath with co-authors emphasize in their study that digitalization of production, accompanied by the growth of computing systems, in practice leads to a significant increase in electricity consumption, which requires energy-efficient planning and the use of energysaving technologies when introducing digital infrastructure [12].

In the future, the evolution of clusters as active participants in innovation and investment activities will facilitate their consolidation into larger production systems based on mechanisms of network interaction between participants. As M. Götz notes, Industry 4.0 opens up further horizons for the spatial development of clusters, allowing them to integrate into larger network structures and develop their own value chains [13]. The same point of view is shared by Polish scientists M. Gancarczyk and J. Gancarczyk, who emphasize the trend emerging in recent years towards the internationalization of clusters, which also affects the mechanisms of strategic management of such structures [14].

\section{Research methods}

This research is based on a deep analysis of existing clusters operating both in the Russian economy and in foreign countries. When developing a program for the strategic development of innovative energy-efficient clusters, the author decomposed the corporate strategies of the analyzed clusters, on the basis of which an optimal strategic development program was synthesized, taking into account, among other strategic development programs, the strategy of its digitalization, the strategy for increasing energy efficiency. In addition, the study used 
the classification method, on the basis of which the author systematized the target indicators of the effectiveness of the implementation of the strategic development program for an innovative energy efficient cluster.

\section{Results}

In the modern innovation economy, the building of strategies is given special attention both by scientists and researchers, and by cluster leaders. This is caused by the fact that one of the main conditions for the efficiency of the cluster structure is a clear systematization of the stages of its construction and further functioning based on a unified strategic development program. Such a program is an interconnected system of plans of various levels, uniting and interconnecting the internal processes and functions of its participants, target strategic indicators of cluster development and the resources required to achieve them. In its structure, at various levels of planning, it consolidates the economic, research, production, technological, social and program resources of the participants around the target indicators, thereby ensuring their coordinated functioning within the cluster as a single mechanism.

The formation of a strategic development program for an innovative energy efficient cluster differs significantly from the development of a strategy for an individual organization or enterprise, since it reveals not just a plan for economic or technological development, but also implies the need to harmonize cluster members within a single structure, develop mechanisms for their effective integration and ensure the widest possible opportunities for joint economic, innovative, industrial and technological development. The structure of the program for the strategic development of an innovative energy efficient cluster developed by the author is presented below (Fig. 1). 


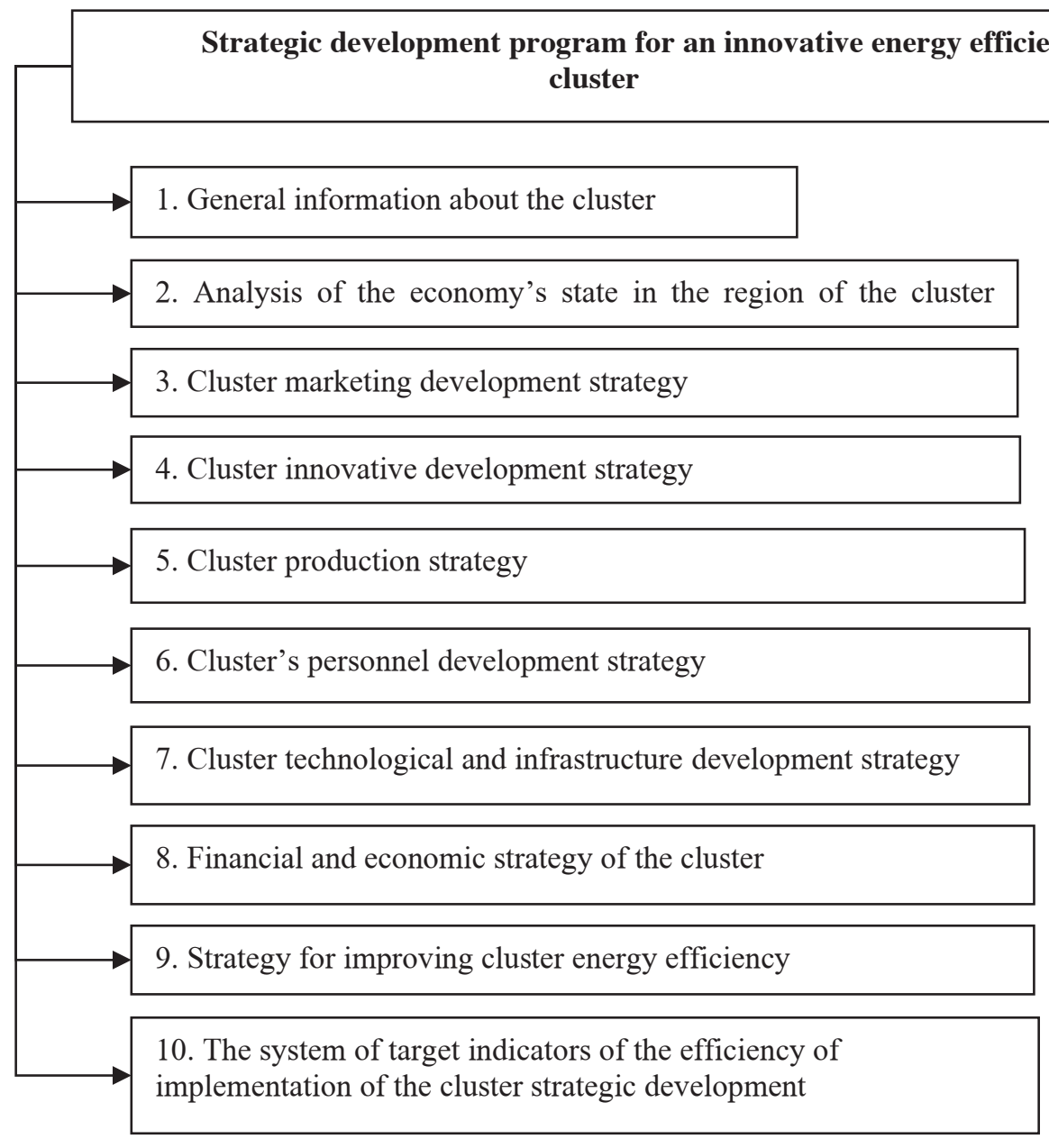

Fig. 1. Structure of the strategic development program for an innovative energy efficient cluster. Source: created by the author

Let's consider separate sections of the program for the strategic development of an innovative energy efficient cluster shown in figure 1. The first and basic section of the program is general information about the cluster. The purpose of this section is a detailed and structured description of both the cluster members themselves and the scheme of their interaction in its structure. It includes a list of its participants, their specialization, as well as their organizational and economic profile: the scale of the organization or enterprise, the number of employees, the economic indicators of their activities, their role and weight in the regional economy, etc. In addition, the concept of cluster policy can be presented in this section, which is one of the important bases of the program for the strategic development of a cluster.

The second section of the strategic development program is an analysis of the economy's state in the region of the cluster location, which is intended to solve a number of applied problems for the subsequent development of the cluster. The specialists analyze the general indicators of the dynamics of the regional economy in recent years, the capacity of the target regional market, indicators of investment activity in the region.

Within the framework of the third section of the strategic development program, a strategy for marketing development of an innovative energy-efficient cluster is being 
developed. It is based on the results of previous marketing research and other marketing activities. Based on these results, this strategy determines the cluster's plans for interaction with target markets, tools and methods for promoting innovative products in them.

An important role in the system of strategic planning of the activity of an innovative energy efficient cluster is played by the strategy of its innovative development. Within this section, first of all, R\&D planning is carried out according to the profile of the cluster members, their research and production cooperation in the framework of the development and commercialization of innovations. The chains of integration of scientific and industrial organizations of the cluster are determined, end-to-end scientific and technological cycles are formed. In addition, this section reveals in detail the existing scientific and technological groundwork of the cluster: scientific developments, research areas of participants, developments introduced into production, existing intellectual property rights.

The production strategy of the cluster contains the main strategic areas for the development of production systems of the cluster members, taking into account both the implementation of their own projects and joint production. In its structure, priority chains of production and technological integration of industrial enterprises that are part of the cluster are recorded. Areas of responsibility and targets for their production volumes are established for individual enterprises.

Within the framework of the cluster's personnel development strategy, the developers define the tasks for increasing and updating their employees for the enterprises and organizations that are part of the cluster. It also plans activities for the intellectual and professional development of existing specialists: retraining programs, advanced training and additional education, training seminars, participation of scientific and engineering specialists in various industry events. Internal systems for testing and assessing the professional training of cluster personnel are being developed and implemented: mandatory passing of internal qualification exams and tests, the use of professional psychological assessment based on an assessment center, etc.

When developing a strategic program for the development of an innovative energyefficient cluster, special attention should be paid to the formation of a strategy for technological and infrastructural development of the cluster, the purpose of which is to plan the technological development of enterprises and organizations of the cluster, as well as the development of its infrastructure complex. On the basis of a comprehensive assessment of the state of equipment and automation systems of the enterprises included in the cluster, plans for their technological modernization are formed. The stages of its implementation correlate with the production strategy, and are also justified taking into account the payback period of new equipment, taking into account the indicators of the cluster's product sales, the level of its economic efficiency and forecasts of its further economic growth. To solve the problems of technological collaboration of enterprises, it is also planned to digitize the cluster in order to create a single software and information environment that unites various types of processes of cluster members.

As part of the financial and economic strategy for the development of an innovative energy efficient cluster, the developers plan its key financial and economic indicators, taking into account the marketing plans, innovative, production, and personnel development of the cluster defined in the previous sections of the strategic program. Based on the current economic dynamics of its participants, as well as data from these strategies, it is planned to distribute financial resources between individual areas of activity and projects of the cluster, as well as the terms of return on investment due to the sale of products and the amount of income for planned periods with the establishment of target strategic indicators of its economic efficiency.

The key role in the development of an innovative energy-efficient cluster is played by the strategy of increasing its energy efficiency. This strategy is based on a system of energy 
saving plans at enterprises and organizations of the cluster on the basis of choosing the most optimal technologies for increasing its energy efficiency. Specialists receive primary data for the formation of this strategy on the basis of an energy survey (energy audit), which allows determining the current levels of use of fuel and energy resources and energy efficiency of cluster members. As a result of its implementation, a list of necessary measures for the modernization of worn out communications and structures, a list of energy-efficient equipment and technologies recommended for implementation is formed.

The final section of the strategic development program is a system of target indicators of the efficiency of implementation of the cluster strategic development, which is developed by specialists. These indicators are used by the leadership of the cluster to assess the pace and trajectory of its development in various projections: marketing, economic, production, technical, technological, etc. (Table 1).

Table 1. Classification of target indicators of the efficiency of the implementation of the strategic development program for an innovative energy efficient cluster

\begin{tabular}{|c|c|c|}
\hline No. & $\begin{array}{l}\text { Category of target indicators of the } \\
\text { efficiency of the implementation of the } \\
\text { strategic development program }\end{array}$ & Indicators of the efficiency \\
\hline \multirow[t]{4}{*}{1.} & \multirow[t]{4}{*}{$\begin{array}{l}\text { Indicators of the efficiency of } \\
\text { marketing development of the cluster }\end{array}$} & $\begin{array}{l}\text { Market share of the cluster in terms of sales in comparison } \\
\text { with competitors }\end{array}$ \\
\hline & & Consumer awareness of the cluster's products \\
\hline & & $\begin{array}{l}\text { The level of sales of cluster products, increased due to } \\
\text { activities for its promotion }\end{array}$ \\
\hline & & $\begin{array}{l}\text { Increase in the share of primary and permanent consumers } \\
\text { of cluster products }\end{array}$ \\
\hline \multirow[t]{5}{*}{2.} & \multirow[t]{5}{*}{$\begin{array}{l}\text { Indicators of the efficiency of } \\
\text { innovative development of the cluster }\end{array}$} & $\begin{array}{l}\text { Number of R\&D projects completed with the development } \\
\text { of an innovation for further commercialization }\end{array}$ \\
\hline & & $\begin{array}{l}\text { Number of patents obtained by scientific organizations of } \\
\text { the cluster }\end{array}$ \\
\hline & & Number of incremental (improving) innovations developed \\
\hline & & $\begin{array}{l}\text { Number of radical innovations developed in the cluster, } \\
\text { leading to the formation of new markets }\end{array}$ \\
\hline & & $\begin{array}{l}\text { Share of successful joint R\&D carried out by two or more } \\
\text { scientific organizations of the cluster }\end{array}$ \\
\hline \multirow[t]{4}{*}{3.} & \multirow[t]{4}{*}{$\begin{array}{l}\text { Indicators of the efficiency of } \\
\text { industrial development of the cluster }\end{array}$} & $\begin{array}{l}\text { Coefficient of integral use of equipment by cluster } \\
\text { enterprises }\end{array}$ \\
\hline & & $\begin{array}{l}\text { The presence in the cluster of a full cycle production with a } \\
\text { closed technological chain }\end{array}$ \\
\hline & & $\begin{array}{l}\text { Share of automation of production processes based on } \\
\text { Industry } 4.0 \text { technologies }\end{array}$ \\
\hline & & $\begin{array}{l}\text { The share of projects implemented on the basis of end-to- } \\
\text { end technological chains uniting } 2 \text { or more enterprises of the } \\
\text { cluster in relation to the total number of projects being } \\
\text { implemented }\end{array}$ \\
\hline \multirow[t]{5}{*}{4.} & \multirow[t]{5}{*}{$\begin{array}{l}\text { Indicators of the efficiency of } \\
\text { personnel development of the cluster }\end{array}$} & $\begin{array}{l}\text { Share of high-performance jobs in organizations and } \\
\text { enterprises of the cluster }\end{array}$ \\
\hline & & $\begin{array}{l}\text { Share of employees of enterprises and organizations of the } \\
\text { cluster with higher and secondary specialized education }\end{array}$ \\
\hline & & $\begin{array}{l}\text { Number of employees who have completed regular } \\
\text { professional development programs }\end{array}$ \\
\hline & & $\begin{array}{l}\text { Share of employees who have completed professional } \\
\text { retraining programs, including those from among specialists } \\
\text { whose professional functions were automated by machine } \\
\text { systems and complexes }\end{array}$ \\
\hline & & $\begin{array}{l}\text { Number of joint personnel development programs } \\
\text { implemented between the cluster and leading universities in } \\
\text { the region }\end{array}$ \\
\hline 5. & & $\begin{array}{l}\text { Share of partially and fully automated subdivisions of } \\
\text { cluster enterprises }\end{array}$ \\
\hline
\end{tabular}




\begin{tabular}{|c|c|c|}
\hline & \multirow{3}{*}{$\begin{array}{l}\text { Indicators of technological and } \\
\text { infrastructural development of the } \\
\text { cluster }\end{array}$} & $\begin{array}{l}\text { Share of digital technologies in the production subsystems } \\
\text { of cluster enterprises }\end{array}$ \\
\hline & & $\begin{array}{l}\text { Share of fully automated technological and production } \\
\text { processes for the production of cluster products }\end{array}$ \\
\hline & & Number of new cluster infrastructure organizations \\
\hline \multirow[t]{4}{*}{6.} & \multirow{4}{*}{$\begin{array}{l}\text { Indicators of financial and economic } \\
\text { development of the cluster }\end{array}$} & Net discounted income from cluster activities \\
\hline & & The level of return on investment in cluster projects \\
\hline & & Weighted average cost of capital \\
\hline & & Payback period of cluster projects \\
\hline \multirow[t]{3}{*}{7.} & \multirow{3}{*}{$\begin{array}{l}\text { Indicators for assessing the energy } \\
\text { efficiency of the cluster }\end{array}$} & Cluster energy efficiency index \\
\hline & & $\begin{array}{l}\text { Indicators of the dynamics of the specific consumption of } \\
\text { various types of fuel and energy resources by enterprises } \\
\text { and organizations of the cluster }\end{array}$ \\
\hline & & Energy intensity of production of a unit the cluster products \\
\hline
\end{tabular}

Classification of indicators for assessing the efficiency of the strategic development program for an innovative energy efficient cluster given in table 1 includes the most frequently used indicators and can be supplemented taking into account the specifics of a particular cluster structure. For example, it can be expanded to include specialized industry indicators that have a significant impact on the development of a cluster as a participant in a particular industry.

\section{Discussion}

The development of the author's model of the Program for the strategic development of innovative energy-efficient clusters is based on the author's in-depth analysis of approaches to strategic planning implemented within the framework of existing clusters. In the very structure of this program, the author took into account all the key strategic areas of cluster development, including, among others, the innovation development strategy, production strategy, human resources development strategy and energy efficiency improvement strategy. In addition, an important section of the Program was the system of target indicators developed by the author, systematized in separate areas and allowing assessment of the success of each strategy. According to the author, the model of the Program for the strategic development of innovative energy-efficient clusters developed in the framework of this study can be successfully used in real projects for the creation and development of cluster formations in various sectors of the economy.

\section{Conclusions}

Strategic planning is one of the most important stages in the activities of all cluster structures without exception, ensuring consistency between their strategic goals and available resources, technologies and capabilities. Modern comprehensive programs for the strategic development of clusters make it possible to solve one of the most important problems that arise when it is necessary to coordinate the management of enterprises and organizations of various levels and scales - to synchronize the systems of their plans and the available resources around jointly implemented innovation and investment projects. When developing the Program for the strategic development of innovative energy-efficient cluster discussed in the study, one of the author's goals was to create a universal model of such a Program in order to ensure the possibility of its practical application in any industry. The author considers the digitalization of the developed Program based on Industry 4.0 technologies as one of the further stages in the development of this study. 


\section{References}

1. R. S. Golov, A. V. Myl'nik, D. A. Prokof'ev, Teoreticheskie osnovy reindustrializacii ekonomiki $\mathrm{V}$ kontekste sistemnoj innovacionnoj modernizacii promyshlennosti. Ekonomika i upravlenie v mashinostroenii. 3, 15-20 (2016)

2. R. S. Golov, A. V. Myl'nik, Transformaciya professional'nyh funkcij cheloveka $v$ usloviyah formirovaniya integrirovannyh avtomatizirovannyh informacionny sistem $v$ promyshlennosti. Ekonomika i upravlenie v mashinostroenii, 1, 5-11 (2017)

3. L. He Zh. Rayman-Bacchus, Y. Wu, Self-organization of industrial clustering in a transition economy: A proposed framework and case study evidence from China, Research Policy, 40(9), 1280-1294 (2011)

4. R. S. Golov, A. V. Myl'nik, Konceptual'nye osnovy formirovaniya innovacionnoinvesticionnyh klasternyh sred $\mathrm{v}$ usloviyah modernizacii ekonomiki. Ekonomika $\mathrm{i}$ upravlenie v mashinostroenii, 1, 32-38 (2014)

5. R. S. Golov, A. V. Myl'nik, Teoreticheskie osnovy formirovaniya innovacionnosinergeticheskih romyshlennyh klasterov. Ekonomika i upravlenie v mashinostroenii, 3, 26-29 (2012)

6. B. Guo, J.-J. Guo, Patterns of technological learning within the knowledge systems of industrial clusters in emerging economies: Evidence from China. Technovation, 31(23), 87-104 (2011)

7. Y. Lu, C. Liu, K. I.-K. Wang, H. Huang, X. Xu, Digital Twin-driven smart manufacturing: Connotation, reference model, applications and research issues. Robotics and Computer-Integrated Manufacturing, 61 (2020)

8. E. Negri, S. Berardi, L. Fumagalli, M. Macchi, MES-integrated digital twin frameworks. Journal of Manufacturing Systems, 56, 58-71 (2020)

9. A. Raj, G. Dwivedi, A. Sharma, A. B. Jabbour, S. Rajak, Barriers to the adoption of industry 4.0 technologies in the manufacturing sector: An inter-country comparative perspective. International Journal of Production Economics, 224 (2020)

10. G. Dalmarco, F. R. Ramalho, A. C. Barrosa, A. L. Soaresac, Providing industry 4.0 technologies: The case of a production technology cluster The Journal of High Technology Management Research, 30, I. 2 (2019)

11. M. Götz The Industry 4.0 Induced Agility and New Skills in Clusters. Foresight and STI Governance, 13(2), 72-83 (2019)

12. A. K. Shukla, R. Nath, P. K. Muhuri, Q. M. Lohani, Energy efficient multi-objective scheduling of tasks with interval type-2 fuzzy timing constraints in an Industry 4.0 ecosystem. Engineering Applications of Artificial Intelligence, 87 (2020)

13. M. Götz, Unpacking the provision of the industrial commons in Industry 4.0 cluster. Economics and Business Review, 5(4), 23-48 (2019)

14. M. Gancarczyk, J. Gancarczyk Proactive international strategies of cluster SMEs. European Management Journal, 36(1), 59-70 (2018) 